\title{
Penerapan Six Sigma Untuk Penyelenggaraan Ujian Akhir Nasional SMU Di Lima Wilayah DKI Jakarta
}

\author{
Prayekti, FKIP-UT, e-mail:prayekti@mail.ut.ac.id \\ Hanafi, FKIP-UT, e-mail:hanafi@mail.ut.ac.id
}

\begin{abstract}
Abstrak : Tujuan penulisan artikel ini dimaksudkan untuk membahas hasil penelitian tentang penerapan Six Sigma pada ujian nasional SMU di Jakarta. Penelitian ini dilaksanakan pada ujian nasional tahun ajaran 2007/2008 di Jakarta dengan menggunakan metode kuesioner survei di lima wilayah Jakarta. Kuesioner disebarkan kepada peserta didik, guru dan pengawas ujian nasional. Sekolah yang menjadi sampel masing-masing wilayah lima sekolah negeri dan swasta. Data dianalisis dengan berpedoman pada Six Sigma yang memiliki empat kegiatan, yaitu perencanaan kualitas (quality planning), pengendalian kualitas (quality control), jaminan kualitas (quality assurance) dan peningkatan kualitas (quality improvement). Hasil penelitian menunjukkkan bahwa semua sekolah pada umumnya telah mempersiapkan diri sebelum menghadapi ujian nasional. Setiap sekolah telah membuat program khusus untuk peserta didik yang akan mengikuti ujian nasional. Program tersebut antara lain: memberikan tambahan materi pelajaran di luar jam pelajaran dan tambahan belajar pada hari Sabtu dan Minggu. Untuk pengendalian kualitas setiap sekolah membentuk panitia khusus yang diketuai kepala sekolah. Ujian nasional menjadi tolok ukur keberhasilan sekolah, sehingga kualitas pembinaan kepada peserta didik menjadi prioritas.
\end{abstract}

Kata kunci: ujian nasional, quality planning, quality control, quality assurance, quality improvement.

\begin{abstract}
This paper discusses the results of research on the application of Six Sigma at the junior national exam in Jakarta. This research was conducted on the implementation of the national exam in academic year 2007/2008 Jakarta using survey questionnaire methods in five areas of Jakarta. Questionnaires distributed to students, teachers and supervisors of national examinations. Data were analyzed based on Six Sigma, which has four areas which include quality planning, quality control, quality assurance and quality improvement. result that all schools have generally been preparing themselves before the national exams. Each school has a special program for students to national exam. The program, among others, provide additional educational materials outside lesson time, and extra studying on Saturday and Sunday. To control the quality of each school formed a special committee chaired by the principal. Because the national exam and the estuary is an important activity of all school activities that have been fostering student for six semesters. National exam to measure the success of the school so that the quality coaching to the students to become primary. If you need to be improved in order to be better. From the students, all students are required to follow all the final semester of the program established by school. Therefore, all students are ready for facing a national exam. Graduation rate of students on national exams students did not disappoint, generally in accordance with the expectations of students, parents, teachers and schools.
\end{abstract}

Key words: National Exams, Six Sigma, quality planning, quality control, quality assurance, quality improvement.

\section{Pendahuluan}

Kualitas yang baik berarti penyedia produk dapat menyajikan produk sesuai standard, memenuhi kebutuhan, keinginan dan harapan pelanggan. Definisi mengenai kualitas yang lebih luas lingkupnya, yaitu kualitas merupakan suatu kondisi dinamis yang berhubungan dengan produk, jasa, manusia, proses, dan lingkungan yang memenuhi atau melebihi harapan. Manajemen kualitas (ISO 8402) pada dasarnya adalah semua kegiatan dari keseluruhan fungsi manajemen yang menetapkan kebijakan kualitas, 
tujuan dan tanggung jawab perusahaan, yang dilaksanakan dengan 4 kegiatan pokok yaitu: perencanaan kualitas (quality planning), pengendalian kualitas (quality control), jaminan kualitas (quality assurance) dan peningkatan kualitas (quality improvement). Sedangkan menurut Juran (1989), supaya kualitas tetap dapat dipertahankan bahkan ditingkatkan, perlu serangkaian tindakan yang saling terkait yaitu: perencananaan kualitas, pengendalian kualitas dan peningkatan kualitas.

Six Sigma merupakan bagian dari program manajemen kualitas yang terdiri dari perencanaan, pengendalian, jaminan dan peningkatan kualitas. Selama ini Six Sigma diterapkan untuk organisasi industri: Penelitian berbasis pada penelitian Goffnett (2004) yang mencoba memandang Six Sigma dari sudut pandang metodologi untuk diterapkan pada bidang pendidikan khususnya pelaksanaan pada kurikulum pelatihan setingkat baccalaureate untuk program terakreditasi manajemen industri. Penelitian Goffnett (2004) menghasilkan bahwa Six Sigma yang sudah dilaksanakan oleh profesional dan praktisi dalam hal ini pengelola program pelatihan. Para pengelola sudah menerapkan pada kurikulum, dan program pelatihan yang disajikan ke mahapeserta didik menghasilkan tingkat kelulusan yang meliputi: pemahaman proses $(91 \%)$, kualitas $(100 \%)$, manajemen $(91 \%)$, bisnis $(82 \%)$ dan komunikasi teknis (73\%). Pelanggan dalam penelitian ini adalah pengguna jasa mahasiwa yang pernah mengikuti pelatihan. Kepuasan pelanggan diukur dengan seberapa jauh efektivitas program, dan tingkat kemudahan diakses setiap saat untuk mendukung program peningkatan kualitas perusahaan. Penelitian yang diusulkan ini berbasis pada penelitian Goffnett (2004), persamaannya adalah penelitian akan berada pada domain pengendalian dan peningkatan kualitas yang dilakukan secara terus menerus. Perencanaan kualitas tidak ditinjau karena menyangkut kebijakan yang sifatnya kualitatif. Jaminan kualitas juga tidak akan ditinjau karena keterbatasan waktu penelitian, jaminan kualitas lulusan SMA dapat diukur setelah mereka menunjukkan kinerja tertentu yang dapat diketahui setelah waktu yang cukup lama, jadi sifatnya jangka panjang. Sedangkan penelitian
Ngadirin (2005) menjawab pertanyaan apakah evaluasi yang saat ini dilaksanakan (ujian nasional) sudah dapat melihat sejauh mana ketercapaian setiap hal yang disebutkan dalam tujuan pendidikan di Indonesia.

Penelitian yang diusulkan ini akan mengisi penelitian Goffnet untuk penerapan di bidang pendidikan menengah, dan melanjutkan penelitian Ngadirin (2005) untuk mengamati seberapa jauh efektifitas dan efisiensi pelaksanaan ujian nasional di DKI Jakarta. Sedangkan Ngadirin (2005) membahas penerapan sistem evaluasi pembelajaran dalam bentuk ujian nasional di tingkat SD, SMU dan SMU di Indonesia. Masalah yang timbul adalah sejauh mana efektivitas dan efisiensi pelaksanaan ujian nasional di Indonesia? Apakah Six Sigma, yang merupakan salah satu metode peningkatan kualitas yang sudah banyak diterapkan di bidang industri tersebut dapat diterapkan untuk bidang pendidikan, khususnya pendidikan menengah?

Penelitian ini akan mendeskripsikan metodologi Six Sigma dan hubungannya dengan dunia pendidikan (khususnya penyelenggaraan Ujian Nasional) untuk lebih dapat memahami konsep peningkatan kualitas yang berkesinambungan. Penelitian ini mencari jawaban untuk pertanyaan: Bagaimana penerapan metodologi Six Sigma untuk suatu program peningkatan kualitas dalam bidang pendidikan, dapatkah digunakan dalam mengevaluasi efektivitas dan efisiensi pelaksanaan Ujian Nasional?

Pendekatan dan konsep yang dilakukan bertujuan untuk menjawab masalah tentang: 1) Mendeskripsikan Six Sigma yang sudah dikenal di dunia bisnis, mencari hubungan dengan dunia pendidikan dengan meninjau metodologi dari sudut pandang pendidikan; 2) Menerapkan metodologi Six Sigma untuk suatu program peningkatan kualitas dalam bidang pendidikan, khususnya untuk mengevaluasi efektivitas dan efisiensi pelaksanaan Ujian Nasional dengan tahapan DMAIC (define, measure, analyze dan improve). Hipotesis yang diuji atau dugaan yang membuktikan bahwa metodologi Six Sigma dapat diterapkan untuk program peningkatan kualitas dalam bidang pendidikan, khususnya untuk mengevaluasi efektivitas dan efisiensi pelaksanaan Ujian Nasional di jenjang pendidikan 
menengah (SMA) dengan mengikuti tahapan DMAIC (define, measure, analyze dan improve).

Berdasarkan latar belakang maka yang menjadi perumusan masalah adalah sejauhmana penerapan metodologi Six Sigma dalam bidang pendidikan, dapatkah digunakan dalam mengevaluasi efektivitas dan efisiensi pelaksanaan Ujian Nasional?

Berdasarkan rumusan masalah maka yang menjadi tujuan penelitian adalah menerapkan metodologi Six Sigma untuk mengevaluasi efektivitas dan efisiensi pelaksanaan Ujian Nasional SMA dengan tahapan DMAIC (define, measure, analyze dan improve)

\section{Kajian Literatur \\ Six Sigma}

Six Sigma pertama kali diperkenalkan kepada publik oleh Motorola (Harry, 1998 dan Sester, 2001) setelah dipergunakan dari tahun 1980 sampai dengan 1985 untuk memenuhi sasaran perusahaan. Pada awalnya dipergunakan untuk meningkatkan kapabilitas proses dan mengurangi produk cacat (defect reduction). Setelah melalui berbagai pemakaian di beberapa perusahaan dan penelitian, memasuki tahun 1990 Six Sigma dipergunakan untuk meningkatkan kinerja proses bisnis yang sifatnya lebih intangibel (intangible). Kegiatan dan capaian Six Sigma dalam operasi perusahaan besar yang sifatnya kaku (ditinjau dari sudut pandang kemudahan melakukan perubahan sesuai kehendak pasar/pelanggan) seperti: GE, Texas Instrument, 3M, Polaroid Sony, Lockheed-Martin (Hahn, et al, 1999) sudah terbukti berhasil baik. Selain perusahaan besar Six Sigma dapat juga diterapkan untuk perusahaan yang lebih kecil dan fleksibel terutama untuk meningkatkan kinerja proses bisnis, misalnya pada: hubungan masyarakat, pembelian/ pengadaan dan di bidang jasa (service sector) (Goh,2002). Temuan terakhir, Six Sigma dapat dipergunakan untuk mengawasi keuangan dan efeknya terhadap perusahaan secara keseluruhan.

Six Sigma menurut Breyfogle (2001) dilihat dari sudut pandang metodologi adalah suatu alat untuk mengukur capaian dan keberhasilan sebuah kegiatan. Terdiri dari 3 definisi, yaitu: a) Merupakan ekspresi statistik, yaitu pengukuran, karena ó adalah konsep dasar statistik untuk menghitung standar deviasi populasi dan mengukur dispersi/variasi rata-rata. Dengan kata lain Six Sigma merupakan ekspresi kinerja proses yang menghasilkan kurang dari 3,4 perseribu produk cacat $($ DPMO $=$ defect part per million opportunities); b) Merupakan cara pandang organisasi yang berfokus pada kepentingan pelanggan untuk melakukan peningkatan proses terus menerus sehingga hasil capaiannya dapat sesempurna mungkin untuk memuaskan pelanggan. Filosofi Six Sigma adalah mengenali adanya korelasi langsung antara jumlah produk cacat, biaya perbaikan dan tingkat kepuasan pelanggan, dan c) Merupakan metodologi peningkatan kinerja yang terdiri dari DMAIC (define, measure, action, improve, control).

Terkait dengan bidang pendidikan Six sigma dapat digunakan untuk melihat seberapa besar pengaruh persiapan yang dilakukan oleh sekolah yang terdiri dari program, peserta didik, dan guru berpengaruh pada hasil yang dicapai peserta didik dalam ujian nasional. Adapun kerangka berpikir Six Sigma seperti yang dipaparkan pada Tabel 1.

Kerangka berpikir ini yang akan diusulkan untuk melaksanakan peingkatan kualitas pada penyelenggaraan Ujian Nasional selanjutnya, yaitu merinci tahapan dan jenis kegiatan serta menentukan subkegiatan yang paling berpengaruh untuk keberhasilan proses seluruhnya (CTQ).

\section{Pendidikan}

Pendidikan merupakan salah satu faktor penting pembangunan di setiap negara. Menurut UndangUndang Nomor 20 Tahun 2003 Pasal 1 butir 14 tentang Sistem Pendidikan Nasional. Pendidikan merupakan usaha sadar dan terencana untuk mengembangkan segala potensi yang dimiliki peserta didik melalui proses pembelajaran. Pendidikan bertujuan untuk mengembangkan potensi anak agar memiliki kekuatan spiritual keagamaan, pengendalian diri, kepribadian, memiliki kecerdasan, berakhlak mulia, serta memiliki keterampilan yang diperlukan sebagai anggota masyarakat dan warga negara. Pendidikan menengah merupakan jenjang pendidikan lanjutan pendidikan dasar, yang dilaksanakan minimal sembilan tahun. Pemerintah 
Prayekti \& Hanafi, Penerapan Six Sigma Untuk Penyelenggaraan Ujian Akhir Nasional SMU Di Lima Wilayah DKI Jakarta

Tabel 1. Kertangka Berpikir Sigma

\begin{tabular}{|c|c|}
\hline Kerangka berpikir & Six Sigma \\
\hline Define & $\begin{array}{l}\text { 1. pilih karakteristik CTQ (Critical to Quality) } \\
\text { 2. tentukan standard kinerja } \\
\text { 3. validasi sistem pengukuran } \\
\text { 4. tentukan kapabilitas produk } \\
\text { 5. tentukan sasaran kinerja }\end{array}$ \\
\hline Measure & 6. identifikasi sumber penyebab variasi \\
\hline Action & $\begin{array}{l}\text { 7. fokus pada penyebab potensial } \\
\text { 8. cari dan temukan hubungan antar variabel }\end{array}$ \\
\hline Improve & $\begin{array}{l}\text { 9. tentukan toleransi operasi untuk kegiatan yang } \\
\text { akan datang } \\
\text { 10. validasi pengukuran system (Xs) } \\
\text { 11. tentukan kapabilitas proses untuk yang akan } \\
\text { datang }\end{array}$ \\
\hline Control & 12. terapkan pengendalian proses terus menerus \\
\hline
\end{tabular}

dalam hal ini Departemen Pendidikan Nasional (Depdiknas) sejak tahun pelajaran 2001/2002 menetapkan ujian nasional sebagai pengganti evaluasi belajar tahap akhir nasional atau Ebtanas. Ujian Nasional berlaku untuk Sekolah Lanjutan Tingkat Pertama (SLTP), Madrasah Tsanawiyah (MTs), Sekolah Dasar (SD), Sekolah Dasar Luar Biasa (SDLB), Sekolah Luar Biasa setingkat SD (SLB), Madrasah Ibtidaiyah (MI), Ebtanas diganti dengan ujian akhir sekolah. Mata pelajaran pada ujian nasional adalah seluruh mata pelajaran yang diajarkan di tingkat SD, SLTP, SMU dan tingkat empat di SMK.

Berdasarkan keputusan menteri, pelaksanaan ujian nasional ini ditetapkan sebagai kewenangan sekolah dan Depdiknas. Depdiknas menyiapkan naskah ujian nasional pada mata pelajaran yang selama ini diebtanaskan, dan kisikisi tes atau stándar kompetensi lulusan untuk mata pelajaran yang tidak disiapkan naskah ujian nasionalnya oleh Depdiknas.

Hasil ujian nasional berfungsi untuk: 1) alat pengendali mutu pendidikan; 2) pendorong, peningkatan mutu pendidikan; 3) bahan pertimbangan dalam menentukan tamat belajar dan predikat prestasi peserta didik; 4) bahan pertimbangan dan seleksi penerimaan peserta didik baru pada jenjang pendidikan yang lebih tinggi. Selanjutnya, tujuan ujian nasional untuk: 1) mengukur pencapaian hasil belajar peserta didik; 2) mengukur mutu pendidikan tingkat nasional/provinsi/kabupaten/kota dan sekolah; 3) mempertanggung jawabkan penyelenggaraan pendidikan per periodik mulai tingkat nasional, provinsi, kabupaten/kota sampai tingkat sekolah. Berdasarkan fungsi dan tujuan ujian nasional tersebut dapat dilihat ada tiga unsur yang berkepentingan dengan pelaksanaan ujian nasional yaitu pemerintah, sekolah, dan peserta didik.

Sementara itu Pemerntah berencana menjadikan hasil ujian nasional SMA sebagai salah satu alat masuk Perguruan tinggi negeri dan penerapannya akan dilakukan pada tahun 2012 dan kebijakan tersebut dimulai tahun 2010. Namun demikian, beberapa rektor perguruan tinggi negeri sepakat menolak hasil ujian nasional digunakan sebagai alat masuk perguruan tinggi negeri dan mensyaratkan hasil ujian nasional yang jujur dan bisa dipertanggung jawabkan. Apabila ingin dipakai sebagai kriteria penerimaan masuk Perguruan tinggi negeri dan Institut Teknologi Bandung hanya akan menggunakannya untuk sebagian kriteria saja, dan ujian nasional tidak bisa dipakai seluruhnya untuk seleksi masuk (Tempo Interaktif, Kamis 07 Mei 2009. 13.59).

\section{Persepsi}

Persepsi dalam Kamus Umum Bahasa Indonesia diartikan sebagai tanggapan atau proses seseorang mengetahui beberapa hal melalui 
pancaindera (2003:866). Persepsi adalah kesadaran intuitif mengenai kebenaran langsung atau keyakinan yang serta merta mengenai sesuatu. Pendapat lain tentang persepsi adalah proses pemahaman ataupun pemberian makna atas suatu informasi terhadap stimulus. Sementara itu stimulus diperoleh dari proses penginderaan terhadap objek, peristiwa ataupun hubungan antar gejala yang selanjutnya diperoses oleh otak (diunduh dari id.wikipedia. org). Terkait dengan hasil ujian nasional, peserta didik akan baik jika persiapan, penguasaan materi ujian, pembekalan materi oleh guru, pelaksanaan ujian nasional, serta sarana dan prasarana telah dinilai baik. Hal tersebut dapat terjadi dimungkinkan sebagai suatu tanggapan terhadap keyakinan yang ditangkap melalui penglihatan, pendengaran, dan pendapat peserta didik serta guru tentang isu-isu yang berkembang mengenai Ujian Nasional yang kemungkinan akan membentuk suatu konsep diri dan dalam menyatakan keinginan yang kemudian akan terefleksi melalui sikap dan perilaku terhadap sesuatu objek tertentu.

Pendapat lain mengemukakan persepsi merupakan proses pemahaman ataupun pemberian makna atas suatu informasi terhadap stimulus. Stimulus diperoleh dari proses penginderaan terhadap objek, peristiwa atau hubungan antar gejala-gejala yang selanjutnya diproses oleh otak sementara itu proses pemahaman terhadap rangsang/stimulus yang diperoleh oleh indera. Pendapat lain menyatakan persepsi merupakan proses dimana individu menjadi sadar akan segala sesuatu dalam lingkungan melalui indera yang dimiliki seperti pendengaran, penglihatan dan sebagainya. Adapun persepsi sosial adalah penilaian-penilaian yang terjadi dalam upaya manusia memahami orang lain yang tentu saja sangat penting namun bukan tugas yang mudah bagi setiap orang. Persepsi sosial terdiri atas tiga elemen yang merupakan petunjuk-petunjuk tidak langsung ketika seseorang menilai orang lain. Tiga elemen tersebut meliputi: 1) pribadi (person), 2) situasi (situation), 3) perilaku.

Proses pembentukan persepsi sosial berdasarkan penilaian pribadi, yang dilakukan dengan cepat ketika melihat penampilan. Umumnya kita memiliki konsep awal tentang beragam situasi berdasarkan pengalaman terdahulu. Situasi ini sering dianggap sebagai naskah kehidupan, semakin banyak pengalaman yang dimiliki seseorang dalam suatu situasi maka semakin terperinci isi naskah yang disusunnya mengenai situasi tertentu. Maka peristiwaperistiwa akan terletak tepat pada tempatnya bagaikan potongan puzzle yang tersusun rapi. Hal tersebut berarti, semakin kaya pengalaman hidup seseorang semakin bijak persepsi sosial yang dibentuknya. Sementara itu elemen perilaku adalah mengidentifikasi perilaku yang diproduksi oleh aktivitas seseorang. Perilaku membutuhkan bukti-bukti yang dapat diamati ketajaman pengamatan seseorang menentukan persepsi sosial yang dibentuknya. Terkait dengan pelaksanaan ujian nasional, maka persepsi sementara apabila persiapan yang dilakukan dengan baik, maka hasil ujian nasionalpun akan baik juga.

\section{Metodologi Penelitian}

Pengambilan sampel berdasarkan teknik purposive random sampling supaya pengamatan yang dilakukan dapat mewakili populasi untuk DKI Jakarta. Sekolah yang diamati adalah SMA di Jakarta Selatan, Jakarta Barat, Jakarta Timur, Jakarta Pusat dan Jakarta Utara. Masing-masing wilayah ditentukan lima sekolah menengah Atas (SMA) negeri maupun swasta, dan jumlah peserta didik yang menjadi responden 30 jurusan IPA dan 30 jurusan IPS sehingga jumlah responden keseluruhannya sebesar 1500 responden.

Pengambilan sampel berdasarkan teknik purposive random sampling supaya pengamatan yang akan dilakukan dapat mewakili populasi untuk DKI Jakarta. Sekolah yang diamati adalah SMA di Jakarta Selatan, Jakarta Barat, Jakarta Timur, Jakarta Pusat dan Jakarta Utara.

\section{Teknik analisis data}

Dalam studi ini analisis data Pengolahan data menggunakan definisi Six Sigma yang ketiga yaitu DMAIC untuk mengamati kinerja pelaksanaan ujian nasional di beberapa sekolah SMA di DKI Jakarta. Six Sigma diterapkan untuk mengevaluasi proses pendidikan dengan 5 tahap: a) define, mendefinisikan masalah yang ada saat ini; b) measure, mengukur ketercapaian suatu program 
pendidikan melalui ujian nasional yang dibandingkan dengan target dan ujian nasional dibandingkan juga dengan hasil pengukuran lain (misalnya raport); c) analyse, menganalisis hasil perbandingan tersebut, d) improve, bagaimana meningkatkan program pelaksanaan pendidikan sehingga hasilnya lebih baik dan e) control, mengenali dengan cepat apabila proses diluar kontrol.

Kegiatan pelaksanaan ujian nasional merupakan serangkaian kegiatan yang dapat dibagi dalam beberapa sub kegiatan. Penelitian ini akan merinci kegiatan menjadi beberapa sub kegiatan dan menentukan bobot masing-masing sub kegiatan berdasarkan hasil wawancara dan telaah literatur. Bobot yang paling besar merupakan CTQ yaitu yang paling mempengaruhi kinerja proses.

\section{Teknik pengumpulan data, dan analisis data}

Pengumpulan data mempergunakan teknik wawancara, kuesioner untuk penyelenggara ujian nasional (Dikdasmen, guru) dan orang tua peserta didik serta pengumpulan data sekunder. Kuesioner akan diuji coba sebelum disebarkan, reliabilitas jawaban responden diuji dengan á Cronbach untuk satu kali pengukuran (one shoot). Sedangkan validitas jawaban responden mempergunakan Analisis Komponen Utama.

\section{Cara menyimpulkan dan menafsirkan hasil penelitian}

Berdasarkan kerangka berpikir DMAIC Six Sigma, kegiatan pelaksanaan ujian nasional dirinci dan diukur untuk dibandingkan dengan target yang sudah ditetapkan. Bila ada produk yang tidak memenuhi syarat (defect) akan dikurangi, dicari penyebabnya, diperbaiki dan ditingkatkan hasilnya (defect reduction). Siklus ini ditinjau untuk semua sub kegiatan.

\section{Hasil Penelitian dan Pembahasan}

Tahapan pada Six Sigma dapat diterapkan pada program sekolah salah satunya adalah kegiatan belajar-mengajar khusus peserta didik kelas XII dalam rangka menghadapi ujian nasional yang merupakan kegiatan intensif sebagai persiapan untuk menghadapi ujian nasional.

Tahap pertama define, menghimpun masalahmasalah yang dihadapi sekolah. Bagaimana persiapan yang dilakukan agar peserta didik kelas XII dapat lulus ujian nasional dengan baik dalam arti semua peserta didik dapat lulus. Masalah tersebut selalu muncul setiap tahun dan sekolah sudah siap dengan membuat program kegiatan sebagai solusinya. Berdasarkan pengalaman selama ini, setiap tahun sekolah selalu membuat program kegiatan untuk menghadapi ujian nasional bagi peserta didik kelas XII. Mulai dari kegiatan perencanaan yaitu membuat jadwal kegiatan untuk penambahan/pemantapan materi pelajaran pada jam pelajaran maupun di luar jam sekolah, memberikan bimbingan belajar bagi peserta didik oleh alumni atau guru lain. Memberitahu atau menyarankan peserta didik mengikuti bimbingan belajar yang terbaik dari beberapa bimbingan belajar yang terdapat di lingkungan tempat tinggal peserta didik dan mengikuti Try out yang diselenggarakan oleh perguruan tinggi negeri maupun swasta.

Tahap kedua measure, sekolah melalui proses belajar dapat mengukur kemampuan peserta didik sehari-hari yang dituangkan di dalam rapor dan membandingkan dengan kemampuan peserta didik menghadapi ujian nasional. Wali kelas umumnya mengetahui kemampuan masingmasing peserta didiknya sehingga dapat memberikan saran dan bimbingan sesuai kebutuhan peserta didik. Upaya guru wali kelas memiliki satu tujuan yaitu peserta didik dapat lulus ujian nasional semuanya.

Tahap ketiga analyse, hasil perbandingan kemampuan peserta didik yang tertuang dalam rapor dengan hasil ujian nasional tahun ajaran sebelumnya dilakukan dievaluasi dan dianalisis. Kemampuan peserta didik (nilai yang diperoleh dalam rapor) tahun lalu dibandingkan dengan nilai ujian nasionalnya dan dianalisis untuk dapat memprediksi nilai rapor peserta didik tahun ini dan kemungkinan perolehan nilai peserta didik pada ujian nasional kali ini.

Tahap keempat improve, upaya yang dilakukan sekolah untuk meningkatkan program pelaksanaan pendidikan dalam hal peningkatan kualitas pembelajaran sehingga hasil ujian nasional menjadi lebih baik. Untuk mengukur ketercapaian suatu program pendidikan yang dikelola sekolah melalui ujian nasional, maka sekolah membuat program sekolah guna 
mengantisipasi perolehan nilai peserta didik pada ujian nasional menjadi optimal. Kegiatan sekolah dalam rangka menghadapi ujian nasional berisikan kegiatan pemantapan materi pelajaran dengan mengulang materi-materi yang dianggap sulit, membahas kisi-kisi yang diperoleh dari internet, mengerjakan soal-soal serta membahas soal-soal ujian nasional tahun-tahun sebelumnya. Semua kegiatan tersebut diselenggarakan dalam rangka menghadapi ujian nasional.

Tahap kelima Control, saat pelaksanaan kegiatan sekolah berlangsung, selalu diawasi dan dipantau oleh koordinator kegiatan untuk masingmasing jurusan IPA, IPS ataupun Bahasa dan dilaporkan kepada kepala sekolah. Apabila ada masalah baik berasal dari tenaga pengajar/ pembimbing yang tidak hadir/tidak baik dalam memberikan materi/membuat peserta didik bingung, atau masalah berasal dari peserta didik (peserta didik sering tidak hadir/malas) atau peserta didik menjadi bingung karena pembimbing tidak baik cara menjelaskan materi, segera diselesaikan. Apabila masalah datangnya dari peserta didik maka koordinator memberi nasihat dan jika perlu dipanggil orang tua untuk mengatasinya. Jika masalah berasal dari tenaga pengajar, maka akan dibahas dalam forum rapat kepala sekolah dengan beberapa guru yang mengajar mata pelajaran yang diujikan melalui ujian nasional. Solusinya memberi peringatan kepada tenaga pengajar yang bersangkutan atau bahkan dapat menggantinya dengan tenaga pengajar lainnya.

Sebelum pelaksanaan kegiatan kepala sekolah dan dewan guru melakukan diskusi membahas tentang pemilihan tenaga pengajar/ pembimbing yang berasal dari luar dalam suatu rapat. Pemilihan tenaga pengajar luar tersebut dengan memperhatikan kualitas dan pengalaman tahun lalu dalam memberikan bimbingan atau mengajar peserta didik kelas XII semua jurusan yang ada, baik IPA, IPS maupun Bahasa. Apabila menurut kesepakatan rapat tenaga tersebut berkualitas maka akan diminta lagi untuk membimbing peserta didik untuk ujian nasional tahun 2008. Apabila dinilai tidak berkualitas maka dicari pengganti yang lebih berkualitas sehingga pada akhir hasil belajar (hasil ujian nasional ) peserta didik menjadi lebih baik lagi dibandingkan tahun lalu. Kepala sekolah dapat memberikan jaminan jika peserta didik mengikuti program sekolah untuk persiapan menghadapi ujian nasional jika cara belajar peserta didik dikelola dengan baik dan benar-benar dibina dengan serius oleh ahlinya dalam hal ini tenaga luar yang berkualitas.

Improve, sekolah selalu berusaha meningkatkan kualitas proses belajar mengajar dengan meningkatkan kemampuan guru dalam mengajar baik secara formal maupun informal. Kepala sekolah selalu mengikutsertakan para guru mengikuti pelatihan atau penataran tentang mata pelajaran ataupun metode pembelajaran dan kurikulum. Kepala sekolah menganjurkan dan memberi ijin kepada para guru untuk melanjutkan pendidikan ke jenjang yang lebih tinggi. Kepala sekolah memiliki pendapat jika para guru memiliki pengalaman mengajar dan berlatar belakang pendidikan tinggi maka kemampuan mengajarpun akan lebih baik. Apabila semua guru telah memiliki latar belakang pendidikan sudah tinggi dan memiliki komitmen dalam mengajar tinggi pula, maka semua program sekolah yang dibuat akan mudah dilaksanakan. Apabila program sekolah dapat berjalan dengan baik maka kepala sekolah hanya melakukan monitoring dan mengontrol saja, jika ada masalah harus segera diselesaikan. Program-program sekolah yang berjalan lancar, semua peserta didik sudah terbiasa mengikuti program sekolah dengan baik dan tidak dianggap sebagai beban maka dapat dipastikan peserta didik kelas XII lebih siap mengahadapi ujian nasional. Berdasarkan pengalaman tahun-tahun sebelumnya hasil dicapai peserta didik juga tidak mengecewakan. Kepala sekolah setiap menghadapi ujian nasional berusaha selalu meningkatkan kualitas pembinaan khususnya kepada peserta didik kelas XII.

Six Sigma yang sudah dikenal di dunia bisnis, dapat dihubungkan dengan dunia pendidikan dalam hal pelaksanaan kegiatan program sekolah menegah atas untuk menghadapi ujian nasional. Setiap sekolah selalu membuat program sekolah yang diperuntukkan peserta didik kelas XII, sebagai persiapan menghadapi ujian nsional. Bahkan, program tersebut telah dibicarakan bersama dengan orang tua peserta didik pada saat awal tahun ajaran peserta didik diterima di 
sekolah tersebut. Dalam pertemuan dengan orang tua peserta didik tersebut membicarakan tentang orientasi sekolah, tata tertib dan dana untuk membiayai seluruh program sekolah selama tiga tahun ke depan. Dana untuk membiayai program sekolah akan dibebankan kepada orang tua peserta didik sebagai uang pangkal/uang pembangunan/uang program, sehingga biaya yang harus dikeluarkan orang tua cukup besar. Besarnya dana bervariasi setiap sekolah berbedabeda tergantung pada jenis dan banyaknya program sekolah. Karena dana tersebut cukup besar, untuk itu dana tersebut dapat diangsur beberapa kali atau selama setahun sangat tergantung kebijaksanaan sekolah masingmasing.

Sementara itu, berdasarkan hasil kuesioner diperoleh data bahwa pada diri peserta didik juga setelah mengikuti program-program yang dilaksanakan sekolah khususnya bimbingan belajar menghadapi ujian nasional berdampak juga pada peserta didik. Peserta didik menjadi lebih termotivasi untuk mempersiapkan diri dalam rangka menghadapi ujian nasional. Di samping itu peserta didik memberikan penilaian kepada aspek yang mendukung pelaksanaan program sekolah dalam rangka pelaksanaan ujian nasional. Peserta didik memberikan penilaian terhadap beberapa aspek yang meliputi perencanaan, penguasaan materi ujian, pembekalan materi oleh guru, pelaksanaan ujian nasional, dan sarana prasarana. Dengan menggunakan skal Likert dan penilaian peserta didik dibuat dengan kriteria nilai skor 1 sampai dengan 4 . nilai skor $1=$ jika peserta didik sangat tidak setuju dengan pernyataan; nilai skor 2 = jika peserta didik tidak setuju dengan pernyataan; nilai skor $3=$ jika peserta didik tidak setuju dengan pernyataan; dan nilai skor $4=$ jika peserta didik sangat setuju dengan pernyataan. Dari hasil analisis yang dilakukan diperoleh bahwa:

Penilaian terkait aspek perencanaan, dengan menggunakan kriteria 1 sampai 4 maka penilaian peserta didik yang meliputi belajar satu sampai dengan dua jam setiap hari dinilai dengan skor rata-rata sebesar 2,782; rajin berlatih menjawab soal-soal ujian nasional tahun lalu dengan nilai skor rata-rata 2,915; rajin berlatih menjawab soal-soal persiapan ujian yang lain memiliki rata- rata skor sebesar 2,865; belajar berkelompok dengan teman-teman memiliki nilai rata-rata sebesar 2,484; mengikuti kegiatan bimbingan belajar di sekolah dengan nilai rata-rata sebesar 3,295; mengikuti kegiatan bimbingan belajar di luar sekolah dengan nilai 2,046; cukup belajar tanpa bimbingan belajar dengan nilai rata-rata 2,895 . Berdasarkan hasil tersebut, umumnya skor nilai yang diperoleh masih lebih kecil dari 3,00 berarti masih harus dilakukan perbaikan untuk aspek perencanaan. Salah satunya guru harus selalu memotivasi peserta didik agar lebih giat belajar untuk persiapan menghadapi ujian nasional. Berdasarkan skor nilai yang diperoleh dari penilaian peserta didik masih lebih rendah dari 3,00. hal tersebut menunjukkan kurangnya persiapan yang dilakukan peserta didik untuk menghadapi ujian nasional. Peserta didik belum memiliki percaya diri yang tinggi untuk menghadapi ujian nasional, padahal sesungguhnya peserta didik telah melakukan persiapan. Peserta didik masih beranggapan bahwa persiapan untuk menghadapi ujian nasional cukup dengan mengikuti kegiatan/program yang dibuat oleh sekolah saja. Penilaian peserta didik terhadap Aspek dalam persiapan dan pelaksanaan ujian nasional Perencanaan yang umumnya rendah terkait dengan kegiatan pribadi, menunjukkan masih kurangnya kepercayaan diri pada peserta didik. Meskipun peserta didik sudah belajar 1 jam sampai dengan 2 jam setiap belum dapat menumbuhkan rasa percaya diri peserta didik. Begitupula dengan latihan yang dilakukan peserta didik menjawab soal-soal ujian nasional tahuntahun sebelumnya belum juga menumbuhkan keyakinan pada peserta didik bahwa dirinya telah siap dan mampu menghadapi ujian nasional. Akan tetapi keikutsertaan peserta didik dalam kegiatan bimbingan belajar di sekolah, telah dapat menumbuhkan sikap tanggung jawab pada diri peserta didik terhadap peraturan dan program sekolah, oleh karena itu penilaian yang diberikan peserta didik tinggi untuk aspek ini.

Untuk aspek penguasaan materi ujian, peserta didik masih belum dapat menilai kemampuan diri sendiri terutama pada mata pelajaran yang diujikan secara nasional. Mata pelajaran tersebut meliputi sudah menguasai materi Bahasa Indonesia dengan baik dinilai 
dengan skor rata-rata 2,737; sudah menguasai materi Bahasa Inggris dengan baik sebesar 2,282; sudah menguasai materi Matematika dengan baik dengan skor 2,160. Seperti telah dijelaskan sebelumnya bahwa segala sesuatu yang menyangkut kemampuan pribadi peserta didik, maka peserta didik akan memberi penilaian yang rendah. Pada aspek penguasaan materi ujian peserta didik juga merasa masih belum mampu (menguasai) materi ujian, sehingga penilaian yang diberikan rata-rata lebih rendah dari 3,00. Hal tersebut juga menunjukkan belum tumbuh rasa percaya diri peserta didik atas kemampuannya pada materi-materi yang diujikan melalui ujian nasional.

Aspek pembekalan materi oleh guru yang meliputi guru memberikan materi tambahan untuk ujian dinilai oleh peserta didik dengan skor ratarata 3,974; guru memberikan arahan tentang tata cara ujian nasional dengan skor rata-rata 3,28; guru memberikan arahan tentang melanjutkan ke jenjang pendidikan lebih tinggi dengan nilai sebesar 3,333; guru memberikan arahan tentang cara mencari pekerjaan dengan rata-rata skor 3,071 . Berbeda dengan pendapat peserta didik terhadap kemampuan diri sendiri, maka pendapat peserta didik terhadap aspek pembekalan materi oleh guru dinilai lebih tinggi dengan nilai rata-rata di atas 3,00.

Aspek pelaksanaan ujian meliputi ujian nasional dimulai tepat waktu dinilai oleh peserta didik dengan skor rata-rata 2,79; ujian nasional selesai tepat waktu sebesar 3,276; mudah untuk mengisi lembar jawaban komputer dengan nilai rata-rata 3,338; kalimat/ Kalimat/pertanyaan pada soal ujian nasional mudah dimengerti dengan nilai sebesar 2,850; Pertanyaan dan soal ujian nasional jelas dibaca (tanda baca, huruf dan angka) dengan nilai sebesar 3,157; Untuk pernyataan terkait Soal ujian nasional mengacu pada SKL dinilai sebesar 3,480; sedangkan untuk pernyataan Pengawas ruang ujian mengawasi dengan baik dinilai sebesar 3,190; Pengawas membuka amplop naskah ujian yang masih tersegel (tertutup rapat) dengan nilai sebesar 3,200; untuk pernyataan terkait dengan Pengawas ujian memeriksa kembali hasil pekerjaannya dinilai dengan skor rata-rata 2,930; dan Pengawas ujian memeriksa pengisian data pribadi dengan nilai sebesar 2,936; serta Pengawas ujian memeriksa penghitaman Lembar Jawaban Komputer sebesar 2,897.

Aspek Sarana Prasarana meliputi Kebersihan ruang Ujian terpelihara dengan baik kebersihan dinilai oleh peserta didik dengan skor rata-rata serbesar 2,981; untuk Penerangan Ruang Ujian dalam kondisi baik dinilai dengan nilai sebesar 2,955; sedangkan untuk Lokasi ujian tersedia toilet (kamar mandi) peserta didik memberikan nilai sebesar 3,170; dan Panitia ujian bekerja dengan baik dinilai dengan skor rata-rata sebesar 3,290.

\section{Penilaian Guru}

Menggunakan skala Likert dengan menggunakan kriteria penilaian 1 sampai dengan 4 maka pendapat para guru terkait aspek perencanaan dinilai baik, dan nilai yang diberikan guru lebih besar dari 3,00. guru merasa yakin bahwa peserta didik telah belajar satu sampai dengan dua jam setiap hari dan memiliki rata-rata skor sebesar 3,166. Rajin berlatih menjawab soal-soal ujian nasional tahun lalu menurut guru lebih lanjut ternyata dinilai dengan skor rata-rata sebesar 3,416, dan peserta didik rajin berlatih menjawab soal-soal persiapan ujian yang lain memiliki skor sebesar 3,33. Untuk hal tersebut, guru-guru banyak yang terlibat dalam kegiatan pembimbingan materi bagi peserta didik kelas XII, sehingga paham betul guru mengetahui tentang proses latihan yang dilakukan peserta didik. Di samping itu guru juga meyakini bahwa peserta didik sudah melakukan belajar berkelompok dengan teman-teman maka nilai yang dipelroleh sebesar 3,333. Terkait dengan bimbingan belajar, guru memiliki keyakinan bahwa semua peserta didik mengikuti kegiatan bimbingan belajar di sekolah dan nilai yang diperoleh sebesar 3,250. Untuk kegiatan di luar jam pelajaran guru berdasarkan pengalaman tahun sebelumnya bahwa peserta didik juga mengikuti kegiatan bimbingan belajar di luar sekolah memiliki skor rata-rata sebesar 3,417, tetapi ada juga pendapat guru yang mengemukakan bahwa peserta didik siap menghadapi ujian nasional cukup belajar tanpa bimbingan belajar dengan skor nilai sebesar 3,080. hal tersebut dimungkinkan dengan kegiatan belajar mengajar di sekolah telah memiliki standar kualitas yang 
cukup untuk menghadapi ujian nasional. untuk hal itu guru mengetahui secara pasti, karena pada umumnya guru turut terlibat dalam kegiatan pembimbingan, terutama dalam penyusunan jadwal kegiatan dan perekrutan tenaga pengajar/ pembimbing dari pihak luar.

Untuk aspek penguasaan materi terutama mata pelajaran Bahasa Indonesia, guru agak pesimis terhadap peserta didik dan memberikan penilaian di bawah 3,00. Guru kurang yakin akan cara belajar peserta didik terhadap mata pelajaran Bahasa Indonesia, karena tidak semua peserta didik menyenangi pelajaran tersebut, dan dianggap bahasa yang digunakan dalam kehidupan sehari-hari mak tidak perlu belajar secara serius. Lain pula dengan pelajaran bahasa Inggris, guru juga kurang yakin terhadap kemampuan peserta didik pada pelajaran itu sehingga nilai yang diberikan rata-rata lebih rendah 3,00. akan tetapi para guru yakin akan kemampuan dan kemauan peserta didik untuk belajar matematika dalam rangka mengahadapi ujian nasional, untuk itu guru menilai lebih besar dari 3,00 yaitu dengan nilai rata-rata 3,420.

Aspek pembekalan materi, guru telah memberikan materi tambahan untuk ujian kepada peserta didik dan nilai rata-rata yang diberikan sebesar 3,250. Sementara itu guru telah memberikan arahan kepada peserta didik tentang tata cara ujian nasional kepada peserta didik nilai yang diberikan rata-rata sebesar 3,580. Guru juga memberikan arahan tentang tata cara untuk melanjutkan ke jenjang pendidikan yang lebih tinggi, dan diberi nilai rata-rata sebesar 3,330. Begitu pula tentang arahan mencari pekerjaan yang diberikan guru, dinilai baik dengan nilai ratarata sebesar 3,420 .

Pada aspek pelaksanaan ujian, menurut guru dimulai tepat waktu dan selesai tepat waktu dengan nilai rata-rata sebesar 3,45. menurut guru kemudahan peserta didik mengisi lembar jawaban dengan nilai rata-rata sebesar 3,50. Sedangkan menurut guru kalimat/ Kalimat/pertanyaan pada soal ujian nasional mudah dimengerti oleh peserta didik dengan nilai rata-rata sebesar 3,580. Pertanyaan dan soal ujian nasional jelas dibaca (tanda baca, huruf dan angka) dinilai sebesar 3,67 , begitu juga dengan soal ujian nasional mengacu pada SKL dinilai sebesar 3,580. menurut guru Pengawas ruang ujian yang bertugas telah melaksanakan tugasnya dengan baik dan dinilai sebesar 3,58. Pengawas telah melakukan tugasnya dengan baik yaitu membuka amplop naskah ujian yang masih tersegel (tertutup rapat) dan dinilai sebesar 3,50. Begitu pula tugasnya memeriksa kembali hasil pekerjaannya telah dilakukan dengan baik maka diberi nilai sebesar 3,58 . Selain itu, pengawas ujian juga memeriksa pengisian data pribadi peserta didik dan penghitaman lembar jawaban komputer dengan baik, maka diberi nilai sebesar rata-rata sebesar 3,50

Untuk aspek Sarana Prasarana guru memberi nilai yang baik baik tentang kebersihan ruang ujian terpelihara dengan baik kebersihan diberi nilai sebesar $(3,50)$, Penerangan Ruang Ujian dalam kondisi baik dengan nilai rata-rata $(3,50)$, dan demikian pula dengan lokasi ujian tersedia toilet (kamar mandi) dengan nilai rata-rata sebesar 3,58 . Secara keseluruhan menurut guru Panitia ujian nasional telah bekerja dengan baik dengan nilai yang diperoleh rata-rata sebesar 3,58.

Pada pelaksanaan ujian nasional pengawas yang bertugas di sekolah berasal dari guru-guru SMA yang mengajar di sekolah lain tetapi masih berada dalam satu rayon atau satu kecamatan dengan sekolah tempat mengawas. Menurut pengawas ujian nasional yang bertugas pada hari pelaksanaan ujian nasional berpendapat bahwa pelaksanaan ujian nasional dimulai tepat waktu dan selesai juga tepat waktu. Penilaian yang diberikan pengawas dengan nilai rata-rata sebesar 3,71. Lebih lanjut pendapat pengawas bahwa peserta didik mudah mengisi lembar jawaban dan nilai diperoleh nilai rata-rata sebesar 3,429 . Begitu pula kalimat/Kalimat/pertanyaan pada soal ujian nasional nampaknya mudah dimengerti oleh peserta didik dengan nilai ratarata sebesar 3,17, Pertanyaan dan soal ujian nasional jelas dibaca (tanda baca, huruf dan angka) dan nilai yang diperoleh rata-rata sebesar 3,50 . Menurut pendapat pengawas, terkait dengan soal ujian nasional sudah mengacu pada SKL, nilai rata-rata yang diperolah sebesar 3,71. Terkait dengan tugasnya sebagai Pengawas ruang ujian yang bertugas mereka merasa telah melaksanakan tugasnya dengan baik dan nilai rata-rata yang diperolah sebesar 3,71 . Sementara 
itu pengawas juga merasa telah melakukan tugasnya dengan baik dalam membuka amplop naskah ujian yang masih tersegel (tertutup rapat), nilai rata-rata sebesar 3,71. Begitu pula kegiatan pengawas dalam memeriksa kembali hasil pekerjaannya, diperoleh nilai rata-rata sebesar 2,86, pengawas ujian juga memeriksa pengisian data pribadi peserta didik dan penghitaman lembar jawaban komputer dengan baik, maka diberi nilai sebesar rata-rata sebesar $(3,14)$.

Untuk aspek Sarana Prasarana guru memberi nilai yang baik baik tentang kebersihan ruang ujian terpelihara dengan baik kebersihan diberi nilai sebesar $(2,86)$, Penerangan Ruang Ujian dalam kondisi baik dengan nilai rata-rata $(2,71)$, dan demikian pula dengan lokasi ujian tersedia toilet (kamar mandi) dengan nilai rata-rata sebesar 3,00 . Secara keseluruhan menurut guru Panitia ujian nasional telah bekerja dengan baik dengan nilai rata-rata sebesar 3,00.

\section{Kelulusan peserta didik}

Melihat hasil kelulusan peserta didik dari sekolah sampel diperoleh, bahwa peserta didik berhasil lulus dengan cukup memuaskan $(89,67 \%)$ dalam arti perencanaan program kegiatan sebagai persiapan menghadapi ujian dapat dikatakan berhasil. Meskipun belum mencapai kelulusan 100 $\%$ namun upaya sekolah sampel untuk menyiapkan peserta didik kelas XII menghadapi ujian nasional patut ditiru oleh sekolah lain. Persiapan menghadapi ujian nasional sudah dimulai sejak awal peserta didik naik ke kelas XII, keseriusan sekolah dalam membina peserta didik sangat menentukan keberhasilan peserta didik dalam ujian nasional. Perhatian dan bimbingan guru terhadap peserta didik memberikan dampak psikologis yang membuat peserta didik lebih percaya diri dan siap menghadapi ujian nasional dan bersaing dengan peserta didik lainnya untuk menjadi yang terbaik.

Banyak faktor yang menyebabkan peserta didik tidak lulus ujian nasional, salah satunya adalah kondisi psikis saat menghadapi soal-soal ujian. Perasaan cemas dan khawatir dapat membuat konsentrasi hilang dan stres sehingga tidak dapat berpikir dengan jernih, yang mengakibatkan salah menjawab soal tersebut.
Terganggunya kesehatan diri peserta didik dapat menyebabkan berkurangnya konsentrasi sehingga daya pikirnya juga menjadi lemah mengakibatkan peserta didik salah menjawab soal-soal yang dikerjakannya.

\section{Simpulan dan Saran Simpulan}

Tahapan pada Six Sigma dapat diterapkan pada program sekolah salah satunya adalah kegiatan belajar-mengajar tambahan khusus bagi peserta didik kelas XII dalam rangka menghadapi ujian nasional, yaitu: a) define, masalah yang dihadapi sekolah adalah bagaimana agar peserta didik kelas XII dapat lulus ujian nasional $100 \%$; b) Berdasarkan pengalaman selama ini, setiap tahun sekolah selalu membuat program kegiatan belajar-mengajar tambahan bagi peserta didik kelas XII; c) measure, sekolah melalui proses belajar dapat mengukur kemampuan peserta didik sehari-hari yang dituangkan di dalam rapor dan dapat memprediksi kesiapan/kemampuan peserta didik menghadapi ujian nasional; d) Analyse, nilai rapor peserta didik dibandingkan dengan hasil ujian nasional tahun ajaran sebelumnya dilakukan dievaluasi dan dianalisis. Untuk Kegiatan sekolah dalam rangka menghadapi ujian nasional berisikan kegiatan pemantapan materi pelajaran dengan mengulang materi-materi yang dianggap sulit, membahas kisikisi yang diperoleh dari internet, mengerjakan soal-soal serta membahas soal-soal ujian nasional tahun-tahun sebelumnya. Semua kegiatan tersebut diselenggarakan dalam rangka menghadapi ujian nasional; e) Control, saat pelaksanaan kegiatan belajar-mengajar tambahan selalu diawasi dan dipantau oleh koordinator kegiatan untuk masing-masing jurusan IPA, IPS ataupun Bahasa dan dilaporkan kepada kepala sekolah. Jika ada masalah baik berasal dari tenaga pengajar/pembimbing atau dari peserta didik segera diatasi; f) Menurut guru, pengawas, peserta didik ujian nasional dimulai dan diakhiri tepat waktu. Peserta didik mengerjakan soal ujian nasional dengan tekun dan tertib. Pengawas telah melakukan tugasnya dengan baik; h) Sarana dan prasarana dinilai baik oleh peserta didik, guru maupun pengawas. Ruang ujian terpelihara dengan baik, penerangan 
ruang ujian dalam kondisi baik, demikian pula dengan lokasi ujian, umumnya tersedia toilet (kamar mandi) yang terpelihara kebersihannya; i) Six Sigma yang sudah dikenal di dunia bisnis, dapat diterapkan pada dunia pendidikan khususnya program sekolah yang diperuntukkan bagi peserta didik kelas XII dalam rangka menghadapi ujian nasional.

\section{Saran}

Six Sigma dapat diterapkan pada pendidikan yaitu pada penyelenggaraan Ujian Nasional untuk jenjang pendidikan SMA, maka tidak menutup kemungkinan dapat diterapkan pada jenjang pendidikan SMP. Namun agar pelaksanaan penerapan Six Sigma dapat optimal, sebaiknya penerapan sudah dimulai pada awal tahun ajaran baru untuk peserta didik kelas VII untuk jenjang SMP dan kelas $X$ untuk jenjang pendidikan SMA.

\section{Pustaka Acuan}

Departemen Pendidikan Nasional. Undang-Undang Nomor. 20 Tahun 2003 Tentang Sistem Pendidikan Nasional

Goffnett, S. 2004. Understanding Six Sigma: Implication for Industry and Education, Journal of Industrial Technology, Volume 20, No.4

Harry, M. 1998. Six Sigma: A Breakthrough strategy for profitability, Quality Progress, Vol.31 No.5

Juran, J. 1989. Juran on Leadership for Quality: an Executive Handbook, Free Press, New York

Pusat Pembinaan dan Pengembangan Bahasa. 2003. Kamus Umum Bahasa Indonesia. Jakarta : Balai Pustaka.

Ngadirin, 2005, Ujian Ahir Nasional sebagai Isu Kritis Pendidikan, Pendidikan Network, http://www. Artikel Pendidikan Network.

Tempo Interaktif, Kamis 07 Mei 2009 